\title{
Penerapan Learning Vector Quantization Pada Pengelompokan Tingkat Kematangan Buah Tomat Berdasarkan Warna Buah
}

\author{
Suwanto Sanjaya \\ Teknik Informatika, UIN Sultan Syarif Kasim Riau \\ Jl. H.R. Soebrantas no. 155 KM. 18 Tuahmadani, Pekanbaru 28129 \\ suwantosanjaya@uin-suska.ac.id
}

\begin{abstract}
Abstrak - Tingkat kematangan buah tomat dapat dilihat dari warna buah. Pada penelitian sebelumnya pernah dilakukan penentuan tingkat kematangan buah tomat menggunakan fitur Hue, Saturation, dan Value (HSV), serta metode klasifikasi Learning Vector Quantization (LVQ). Pada penelitian tersebut menggunakan data citra buah tomat dari satu sisi. Pada kenyataanya, tidak semua buah tomat memiliki penyebaran warna yang sama disetiap sisinya. Oleh karena itu dibutuhkan teknik untuk merata-ratakan informasi warna dari beberapa sisi buah. Berdasarkan permasalahan tersebut, maka data citra buah tomat yang digunakan diambil dari empat sisi untuk setiap buahnya. Total data citra yang digunakan adalah $\mathbf{4 0 0}$ citra dari empat sisi dan setelah dirata-ratakan menjadi 100 data. Level kematangan buah tomat yang digunakan adalah 5 level yaitu green, breakers, turning, pink, light red, dan red. Proses pelatihan dan pengujian bobot optimal menggunakan K-Fold Cross Validation. Berdasarkan hasil pengujian, rata-rata akurasi tertinggi adalah mencapai $87,25 \%$ yang diuji menggunakan 400 citra setiap sisi buah. Berdasarkan hasil pengujian tersebut dapat disimpulkan nilai HSV yang dihasilkan dari rata-rata penggabungan citra empat sisi dapat dijadikan alternatif untuk menentukan tingkat kematangan buah tomat karena dapat meningkatkan akurasi walaupun tidak terlalu signifikan.
\end{abstract}

Kata Kunci - HSV, LVQ, pengelompokan, tomat, warna.

\section{PENDAHULUAN}

Buah tomat atau dalam bahasa latin disebut dengan Lycopersicum esculentum Mill merupakan jenis tanaman hortikultura. Salah satu jenisnya adalah Lycopersicon lycopersicum atau sering disebut tomat plum [1]. Waktu kematangan buah tomat relatif cepat sehingga dibutuhkan teknik pemilihan untuk menghindari kebusukan buah [2] Pemilihan buah tomat dapat dilakukan dengan melihat beberapa cara. Pada umumnya dilihat dari warna buah. Menurut USDA [3], buah tomat dikelompokkan menjadi 6 level kematangan yaitu warna green, breakers, turning, pink, light red, dan red.
Salah satu penelitian tentang klasifikasi tingkat kematangan buah tomat berdasarkan warna buah yang pernah dilakukan adalah pengenalan tingkat kematangan buah tomat menggunakan HSV dan LVQ [4]. Training set pada penelitian tersebut menggunakan citra buah tomat yang diambil dari satu sisi dengan hasil akurasi sebesar $83,75 \%$. Pada kenyataanya, tidak semua buah tomat memiliki penyebaran warna yang sama disetiap sisinya.

Berdasarkan permasalahan tersebut, maka pada penelitian ini digunakan training set hasil dari rata-rata warna keempat sisi buah tomat pada citra diam. Hal ini dilakukan agar seluruh informasi warna buah tomat menjadi lebih merata dan diharapkan dapat meningkatkan akurasi. Metode yang digunakan tetap sama dengan penelitian [4] yaitu menggunakan HSV dan LVQ.

Data citra yang digunakan pada penelitian ini bersumber dari buah tomat sebanyak 100 sampel. Sampel menggunakan jenis tomat plum. Citra diambil menggunakan kamera DSLR. Hasil klasifikasi terdiri dari 5 level kelas yaitu warna green, turning, pink, light red, dan red. Kelas breaker di satukan dengan kelas green karena lebih dominan berwarna hijau gelap. Kelas breaker hanya $10 \%$ mengandung warna kuning kecoklatan di permukaannya [3] seperti pada Gambar 1 .

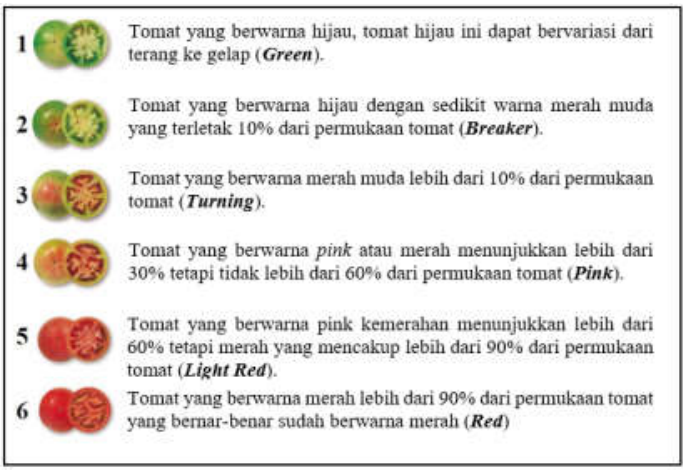

Gambar 1. Level Kematangan Buah Tomat

Penelitian terkait dengan penggunaan LVQ sebagai metode klasifikasi adalah untuk klasifikasi identitas wajah [5], klasifikasi data KDD Cup 99 [6], klasifikasi mutu jeruk nipis [7]. Penelitian lain yang berhubungan dengan penggunaan HSV sebagai fitur adalah pengenalan kualitas ikan gurami [8], 
klasifikasi citra buah [9], klasifikasi buah apel [10] dan klasifikasi buah tomat [11].

\section{METODE PENELITIAN}

Tahapan pengelompokan tingkat kematangan buah tomat berdasarkan warna buah menggunakan LVQ terdiri dari enam tahapan utama yaitu pengumpulan data, pra-pemrosesan, ekstraksi ciri, pembagian data, pelatihan, dan pengujian seperti pada Gambar 2.

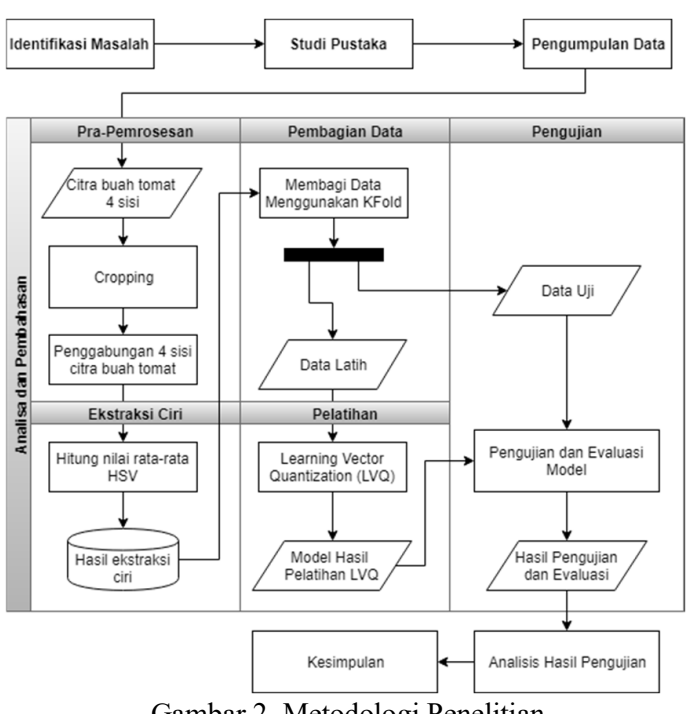

Gambar 2. Metodologi Penelitian

\section{A. Pengumpulan Data}

Data bersumber dari 100 buat tomat yang difoto dengan latar belakang kertas putih. Buah tomat yang digunakan terdiri dari 20 buah tomat warna green, 20 buah tomat warna turning, 20 buah tomat warna pink, 20 buah tomat warna light red, dan 20 buah tomat warna red.

Setiap buah tomat difoto keempat sisinya yaitu sisi bagian depan, bagian belakang, bagian kanan, dan bagian kiri, sehingga satu buah tomat menghasilkan 4 citra.

\section{B. Pra-Pemrosesan}

Citra asli buah tomat memiliki dimensi yang bervariasi. Ukuran dimensi width citra tersebut antara 1300 pixel sampai dengan 1600 pixel, dan height antara 1600 pixel sampai dengan 1800 pixel. Selanjutnya setiap sisi citra dilakukan pemotongan (cropping) seperti pada Gambar 3. Pemotongan citra dilakukan dengan beberapa ukuran untuk kepentingan pengujian. Ukuran pemotongan citra yang digunakan adalah $100 \times 100$ pixel, $300 \times 300$ pixel, $600 \times 600$ pixel, dan $1000 \times 1000$ pixel.

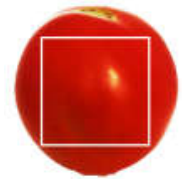

Gambar 3. Proses pemotongan citra buah tomat

Setelah dihasilkan dataset citra hasil pemotongan dari keempat sisi buah sebanyak 400 citra, maka dilakukan proses penggabungan citra dengan merata-ratakan nilai Red, Green, dan Blue (RGB) dari citra keempat sisi buah seperti pada Gambar 4.

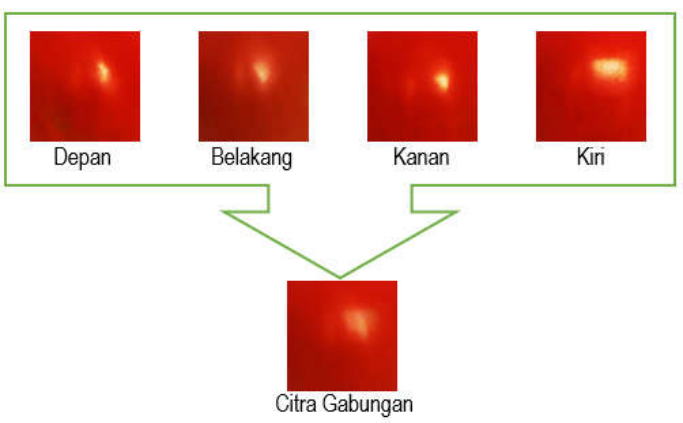

Gambar 4. Proses penggabungan citra berdasarkan citra hasil cropping dari keempat sisi buah tomat

\section{Ekstraksi Ciri}

Proses yang dilakukan pada ekstraksi ciri adalah melakukan ekstrasi ciri HSV dari 100 data citra hasil penggabungan menggunakan Hexcone model [11]. Langkah-langkahnya sebagai berikut:

1. Konversi nilai RGB dalam rentang 0 s.d 1;

2. Hitung nilai $\mathrm{V}=\max (\mathrm{R}, \mathrm{G}, \mathrm{B})$;

3. Hitung nilai $X=\min (R, G, B)$;

4. Hitung nilai $\mathrm{S}=\frac{\mathrm{V}-\mathrm{X}}{\mathrm{V}}$;

5. Hitung nilai $r=\frac{V-R}{V-X}, g=\frac{V-G}{V-X}, b=\frac{V-B}{V-X}$;

6. Jika $\mathrm{R}=\mathrm{V}$ maka:

a. Jika $\mathrm{G}=\mathrm{X}$ maka: $\mathrm{H}=5+\mathrm{b}$

b. Jika tidak maka: $\mathrm{H}=1-\mathrm{g}$

Jika $\mathrm{G}=\mathrm{V}$ maka:

a. Jika $\mathrm{B}=\mathrm{X}$ maka: $\mathrm{H}=1+\mathrm{r}$

b. Jika tidak maka: $\mathrm{H}=3-\mathrm{b}$

Selain dari itu maka:

a. Jika $\mathrm{R}=\mathrm{X}$ maka: $\mathrm{H}=3+\mathrm{g}$

b. Jika tidak maka: $\mathrm{H}=5-\mathrm{r}$

7. Hitung nilai $\mathrm{H}$ akhir yaitu $\mathrm{H}=\frac{\mathrm{H}}{6}$

Langkat tersebut dilakukan pada setiap pixel citra. Berdasarkan hasil perhitungan tersebut, Selanjutnya hitung rata-rata nilai $\mathrm{H}, \mathrm{S}$, dan $\mathrm{V}$. hasil akhir dari tahap ini adalah tiga nilai yaitu rata-rata nilai Hue, rata-rata nilai Saturation, dan rata-rata nilai Value. 


\section{Pembagian Data}

Pembagian data latih dan uji dibagi menggunakan teknik K-Fold Cross Validation [12]. Jumlah fold (k) yang digunakan adalah 10. Langkahlangkah pembagian data yang dilakukan adalah sebagai berikut.

1. Tentukan jumlah subset sebanyak nilai $\mathrm{k}$ yang ditetapkan.

2. Jadikan k-1 (9 subset) sebagai data latih, dan sisanya (1 subset) sebagai data uji.

3. Lakukan proses kedua sampai seluruh subset mendapat kesempatan yang sama sebagai data uji dan data latih.

\section{E. Pelatihan}

Tahap pelatihan merupakan tahapan pembelajaran data menggunakan algoritme. Proses pelatihan bertujuan untuk menghitung bobot optimal sehingga menghasilkan bobot terbaik. Algoritme LVQ [13] dan [14] adalah sebagai berikut.

1. Inisialisasi vektor masukan (x) beserta kelas/targetnya $\left(\mathrm{T}_{\mathrm{x}}\right)$, vektor pewakil $(\mathrm{m})$ setiap kelas, nilai maksimum iterasi, laju pembelajaran $(\alpha)$, dan pengurangan laju pembelajaran.

2. Periksa kondisi berhenti pada iterasi, jika kondisi sudah mencapai maksimum maka berhenti, jika tidak maka lakukan langkah berikutnya.

3. Lakukan langkah 3 s.d 7 untuk setiap vektor masukan (x).

4. Hitung Jarak Euclidean (J) antara vektor w dan vektor $\mathrm{x}$, kemudian ambil Target $\left(\mathrm{T}_{\mathrm{p}}\right)$ dari vektor pemenang yaitu jarak yang terkecil.

5. Perbarui nilai vektor $m$

Jika $T_{x}=T_{p}$, maka perbarui bobot menggunakan persamaan: $\mathbf{m}_{\mathbf{c}}(\mathbf{t}-\mathbf{1})=\mathbf{m}_{\mathbf{c}}(\mathbf{t})+\boldsymbol{\alpha}(\mathbf{t})\left[\mathbf{x}(\mathbf{t})-\mathbf{m}_{\mathbf{c}}(\mathbf{t})\right]$
Jika $T_{x} \neq T_{p}$, maka perbarui bobot menggunakan persamaan: $\mathbf{m}_{\mathbf{c}}(\mathbf{t}-\mathbf{1})=\mathbf{m}_{\mathbf{c}}(\mathbf{t})-\boldsymbol{\alpha}(\mathbf{t})\left[\mathbf{x}(\mathbf{t})-\mathbf{m}_{\mathbf{c}}(\mathbf{t})\right]$

6. Perbarui nilai $\alpha$ dengan mengurangi nilai $\alpha$, dan tambahkan nilai iterasi.

\section{Kembali ke Langkah 2}

\section{F. Pengujian}

Pengujian dilakukan dengan beberapa skenario yaitu menguji pengaruh ukuran citra, jumlah iterasi (epoch), serta learning rate $(\alpha)$ pada tahap pembelajaran. Setelah dihasilkan bobot hasil pelatihan, maka dihitung hasil akurasi setiap skenario pengujian. Berdasarkan teknik $K$-Fold Cross Validation, maka dilakukan proses pengujian seperti berikut.

1. Hitung matriks pengujian (Confussion Matrix) untuk setiap fold (k) yang diuji [15].

2. Hitung rata-rata hasil akurasi setiap fold (k).

Setiap skenario pengujian yang dilakukan, diambil bobot hasil pelatihannya. Bobot tersebut akan diuji kembali menggunakan citra asli sebanyak 400 citra sebelum digabungkan.

\section{HASIL DAN PEMBAHASAN}

Total citra yang dihasilkan dari akuisisi citra adalah 400 citra. Beberapa contoh citra buah tomat hasil akuisisi yang digunakan pada penelitian ini dapat dilihat pada Gambar 5. Hasil pemotongan citra buah tomat dapat dilihat pada Gambar 6. Hasil penggabungan citra dari keempat sisi buah tomat dapat dilihat pada Gambar 7.

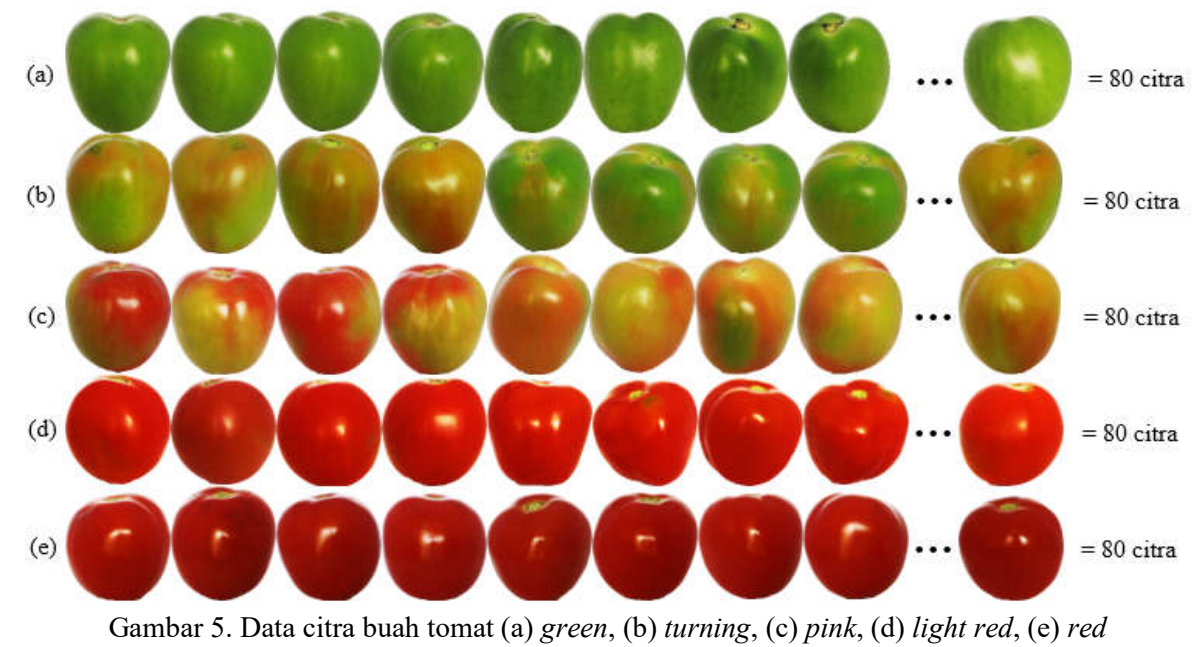


(a)

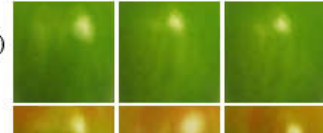

(b)

(c)

(d)

(e)

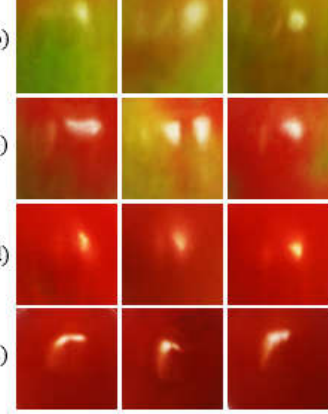

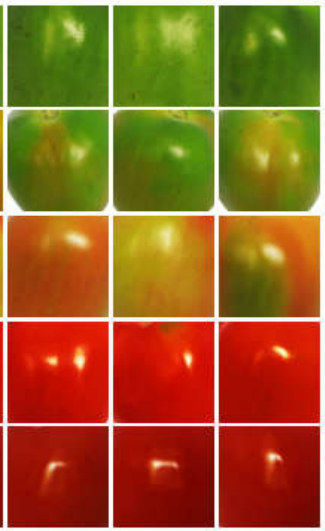
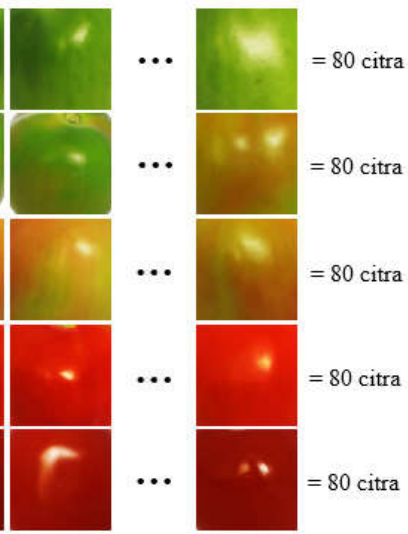

Gambar 6. Hasil pemotongan citra buah tomat (a) green, (b) turning, (c) pink, (d) light red, (e) red

(a)

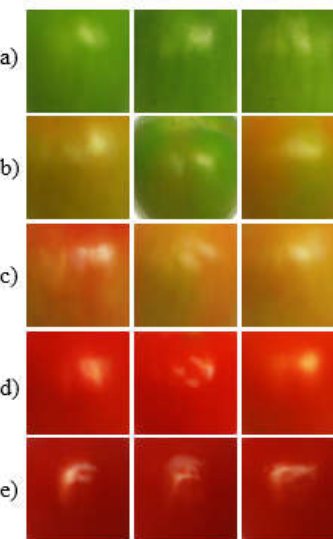

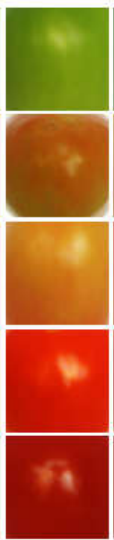

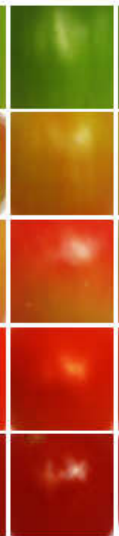

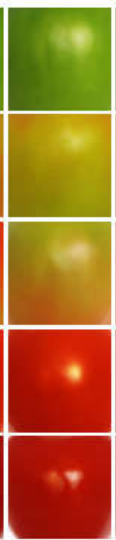

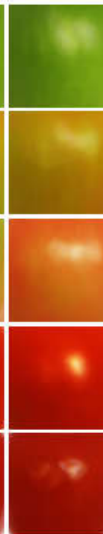

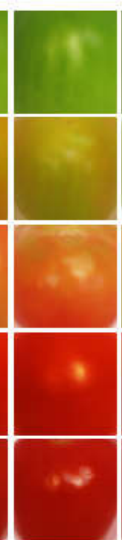

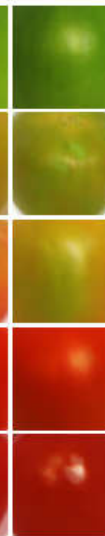

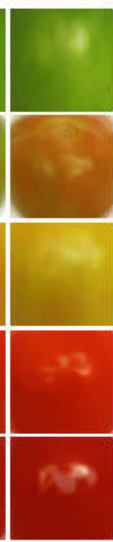

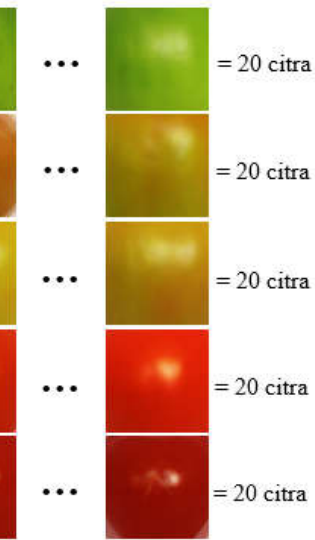

Gambar 7. Hasil penggabungan keempat sisi citra buah tomat (a) green, (b) turning, (c) pink, (d) light red, (e) red

Hasil penggabungan citra menghasilkan 20 citra setiap kelas, sehingga total citra hasil penggabungan berjumlah 100 citra seperti pada Gambar 7. Nilai rata-rata HSV dihitung berdasarkan 100 citra tersebut. Hasil ekstraksi ciri nilai rata-rata HSV dapat dilihat pada Tabel 1. Target atau kelas yang digunakan adalah tingkat kematangan buah yaitu (1) green, (2) turning, (3) pink, (4) light red, dan (5) red.

Tabel 1. Hasil ekstraksi ciri rata-rata nilai HSV

\begin{tabular}{|r|l|l|l|c|}
\hline No & \multicolumn{1}{|c|}{$\mathbf{H}$} & \multicolumn{1}{|c|}{ S } & \multicolumn{1}{|c|}{ V } & Kelas \\
\hline $\mathbf{1}$ & 0,23395 & 0,91553 & 0,49121 & 1 \\
\hline $\mathbf{2}$ & 0,23664 & 0,88693 & 0,48717 & 1 \\
\hline $\mathbf{3}$ & 0,21527 & 0,8971 & 0,55139 & 1 \\
\hline $\mathbf{4}$ & 0,20466 & 0,89723 & 0,58473 & 1 \\
\hline $\mathbf{5}$ & 0,21787 & 0,83494 & 0,57496 & 1 \\
\hline $\mathbf{6}$ & 0,2141 & 0,85744 & 0,58757 & 1 \\
\hline $\mathbf{7}$ & 0,21749 & 0,85023 & 0,58258 & 1 \\
\hline $\mathbf{8}$ & 0,21831 & 0,87473 & 0,59184 & 1 \\
\hline $\mathbf{9}$ & 0,22313 & 0,87247 & 0,52939 & 1 \\
\hline $\mathbf{1 0}$ & 0,21415 & 0,85219 & 0,58382 & 1 \\
\hline $\mathbf{1 1}$ & 0,22677 & 0,89128 & 0,54065 & 1 \\
\hline $\mathbf{1 2}$ & 0,20102 & 0,90036 & 0,5751 & 1 \\
\hline $\mathbf{1 3}$ & 0,21237 & 0,8773 & 0,61722 & 1 \\
\hline
\end{tabular}

\begin{tabular}{|c|l|l|l|c|}
\hline No & \multicolumn{1}{|c|}{ H } & \multicolumn{1}{|c|}{ S } & \multicolumn{1}{|c|}{$\mathbf{V}$} & Kelas \\
\hline $\mathbf{1 4}$ & 0,20203 & 0,88954 & 0,60133 & 1 \\
\hline $\mathbf{1 5}$ & 0,20854 & 0,82558 & 0,69633 & 1 \\
\hline $\mathbf{1 6}$ & 0,20481 & 0,86632 & 0,70497 & 1 \\
\hline $\mathbf{1 7}$ & 0,20778 & 0,8806 & 0,67118 & 1 \\
\hline $\mathbf{1 8}$ & 0,21331 & 0,85246 & 0,58735 & 1 \\
\hline $\mathbf{1 9}$ & 0,20698 & 0,88739 & 0,6624 & 1 \\
\hline $\mathbf{2 0}$ & 0,20987 & 0,80751 & 0,68878 & 1 \\
\hline $\mathbf{2 1}$ & 0,12916 & 0,93463 & 0,5629 & 2 \\
\hline $\mathbf{2 2}$ & 0,1887 & 0,84773 & 0,50525 & 2 \\
\hline $\mathbf{2 3}$ & 0,13534 & 0,96297 & 0,58107 & 2 \\
\hline $\mathbf{2 4}$ & 0,079213 & 0,9382 & 0,64579 & 2 \\
\hline $\mathbf{2 5}$ & 0,094528 & 0,96501 & 0,68925 & 2 \\
\hline $\mathbf{2 6}$ & 0,14557 & 0,95139 & 0,65923 & 2 \\
\hline $\mathbf{2 7}$ & 0,12658 & 0,95206 & 0,64148 & 2 \\
\hline $\mathbf{2 8}$ & 0,14941 & 0,93012 & 0,59989 & 2 \\
\hline $\mathbf{2 9}$ & 0,17655 & 0,75258 & 0,63327 & 2 \\
\hline $\mathbf{3 0}$ & 0,09241 & 0,9298 & 0,65275 & 2 \\
\hline $\mathbf{3 1}$ & 0,096637 & 0,95998 & 0,6372 & 2 \\
\hline $\mathbf{3 2}$ & 0,14996 & 0,96366 & 0,64447 & 2 \\
\hline $\mathbf{3 3}$ & 0,14628 & 0,91858 & 0,67226 & 2 \\
\hline $\mathbf{3 4}$ & 0,099186 & 0,9094 & 0,74513 & 2 \\
\hline $\mathbf{3 5}$ & 0,11477 & 0,8463 & 0,70452 & 2 \\
\hline $\mathbf{3 6}$ & 0,12675 & 0,90633 & 0,64421 & 2 \\
\hline & & & & \\
\hline
\end{tabular}




\begin{tabular}{|c|l|l|l|c|}
\hline No & \multicolumn{1}{|c|}{$\mathbf{H}$} & \multicolumn{1}{|c|}{ S } & \multicolumn{1}{|c|}{ V } & Kelas \\
\hline $\mathbf{3 7}$ & 0,11439 & 0,92917 & 0,59264 & 2 \\
\hline $\mathbf{3 8}$ & 0,17741 & 0,86072 & 0,60331 & 2 \\
\hline $\mathbf{3 9}$ & 0,11617 & 0,95295 & 0,70614 & 2 \\
\hline $\mathbf{4 0}$ & 0,13249 & 0,94418 & 0,61921 & 2 \\
\hline $\mathbf{4 1}$ & 0,06437 & 0,896 & 0,7415 & 3 \\
\hline $\mathbf{4 2}$ & 0,11594 & 0,90359 & 0,67328 & 3 \\
\hline $\mathbf{4 3}$ & 0,10412 & 0,91238 & 0,73127 & 3 \\
\hline $\mathbf{4 4}$ & 0,086033 & 0,89596 & 0,80396 & 3 \\
\hline $\mathbf{4 5}$ & 0,040068 & 0,92983 & 0,81278 & 3 \\
\hline $\mathbf{4 6}$ & 0,12116 & 0,83458 & 0,68081 & 3 \\
\hline $\mathbf{4 7}$ & 0,078929 & 0,86192 & 0,84062 & 3 \\
\hline $\mathbf{4 8}$ & 0,072294 & 0,86253 & 0,86283 & 3 \\
\hline $\mathbf{4 9}$ & 0,15956 & 0,91704 & 0,58478 & 3 \\
\hline $\mathbf{5 0}$ & 0,13854 & 0,91829 & 0,70881 & 3 \\
\hline $\mathbf{5 1}$ & 0,13675 & 0,88214 & 0,68626 & 3 \\
\hline $\mathbf{5 2}$ & 0,11609 & 0,92042 & 0,65649 & 3 \\
\hline $\mathbf{5 3}$ & 0,1066 & 0,89484 & 0,78405 & 3 \\
\hline $\mathbf{5 4}$ & 0,13752 & 0,82928 & 0,70428 & 3 \\
\hline $\mathbf{5 5}$ & 0,070632 & 0,92644 & 0,8005 & 3 \\
\hline $\mathbf{5 6}$ & 0,078911 & 0,80328 & 0,80928 & 3 \\
\hline $\mathbf{5 7}$ & 0,088825 & 0,90286 & 0,75441 & 3 \\
\hline $\mathbf{5 8}$ & 0,10264 & 0,92345 & 0,72277 & 3 \\
\hline $\mathbf{5 9}$ & 0,10647 & 0,9089 & 0,73233 & 3 \\
\hline $\mathbf{6 0}$ & 0,12363 & 0,92478 & 0,66249 & 3 \\
\hline $\mathbf{6 1}$ & 0,015952 & 0,96182 & 0,78816 & 4 \\
\hline $\mathbf{6 2}$ & 0,020139 & 0,94859 & 0,82356 & 4 \\
\hline $\mathbf{6 3}$ & 0,025726 & 0,98425 & 0,81587 & 4 \\
\hline $\mathbf{6 4}$ & 0,022823 & 0,98446 & 0,87957 & 4 \\
\hline $\mathbf{6 5}$ & 0,022341 & 0,97249 & 0,80708 & 4 \\
\hline $\mathbf{6 6}$ & 0,022856 & 0,9742 & 0,80541 & 4 \\
\hline $\mathbf{6 7}$ & 0,019339 & 0,98687 & 0,76552 & 4 \\
\hline $\mathbf{6 8}$ & 0,018561 & 0,98458 & 0,76153 & 4 \\
\hline $\mathbf{6 9}$ & 0,022837 & 0,98635 & 0,72427 & 4 \\
\hline $\mathbf{7 0}$ & 0,023783 & 0,98136 & 0,73956 & 4 \\
\hline $\mathbf{7 1}$ & 0,028955 & 0,95431 & 0,82723 & 4 \\
\hline $\mathbf{7 2}$ & 0,029358 & 0,95017 & 0,79671 & 4 \\
\hline $\mathbf{7 3}$ & 0,026651 & 0,94326 & 0,83008 & 4 \\
\hline $\mathbf{7 4}$ & 0,023802 & 0,95175 & 0,86961 & 4 \\
\hline $\mathbf{7 5}$ & 0,028013 & 0,93507 & 0,84711 & 4 \\
\hline $\mathbf{7 6}$ & 0,025096 & 0,95281 & 0,82731 & 4 \\
\hline & & & & \\
\hline
\end{tabular}

\begin{tabular}{|r|l|l|l|c|}
\hline No & \multicolumn{1}{|c|}{$\mathbf{H}$} & \multicolumn{1}{|c|}{$\mathbf{S}$} & \multicolumn{1}{|c|}{$\mathbf{V}$} & Kelas \\
\hline $\mathbf{7 7}$ & 0,028224 & 0,94079 & 0,78766 & 4 \\
\hline $\mathbf{7 8}$ & 0,024372 & 0,9682 & 0,7989 & 4 \\
\hline $\mathbf{7 9}$ & 0,027391 & 0,95632 & 0,85161 & 4 \\
\hline $\mathbf{8 0}$ & 0,027929 & 0,93459 & 0,88212 & 4 \\
\hline $\mathbf{8 1}$ & 0,016721 & 0,95668 & 0,61701 & 5 \\
\hline $\mathbf{8 2}$ & 0,01997 & 0,95837 & 0,64388 & 5 \\
\hline $\mathbf{8 3}$ & 0,019862 & 0,95993 & 0,62681 & 5 \\
\hline $\mathbf{8 4}$ & 0,018881 & 0,9455 & 0,65788 & 5 \\
\hline $\mathbf{8 5}$ & 0,014578 & 0,96697 & 0,60214 & 5 \\
\hline $\mathbf{8 6}$ & 0,023763 & 0,92926 & 0,72129 & 5 \\
\hline $\mathbf{8 7}$ & 0,017875 & 0,98075 & 0,6169 & 5 \\
\hline $\mathbf{8 8}$ & 0,012028 & 0,97618 & 0,64376 & 5 \\
\hline $\mathbf{8 9}$ & 0,017564 & 0,96842 & 0,60998 & 5 \\
\hline $\mathbf{9 0}$ & 0,020609 & 0,78202 & 0,65599 & 5 \\
\hline $\mathbf{9 1}$ & 0,022884 & 0,94377 & 0,56795 & 5 \\
\hline $\mathbf{9 2}$ & 0,023678 & 0,96347 & 0,64358 & 5 \\
\hline $\mathbf{9 3}$ & 0,018435 & 0,97334 & 0,59995 & 5 \\
\hline $\mathbf{9 4}$ & 0,01544 & 0,96935 & 0,62031 & 5 \\
\hline $\mathbf{9 5}$ & 0,026481 & 0,85859 & 0,69287 & 5 \\
\hline $\mathbf{9 6}$ & 0,03096 & 0,89474 & 0,60675 & 5 \\
\hline $\mathbf{9 7}$ & 0,024878 & 0,94447 & 0,62402 & 5 \\
\hline $\mathbf{9 8}$ & 0,029793 & 0,91513 & 0,64054 & 5 \\
\hline $\mathbf{9 9}$ & 0,018494 & 0,96452 & 0,59974 & 5 \\
\hline $\mathbf{1 0 0}$ & 0,017359 & 0,93664 & 0,60708 & 5 \\
\hline & & & & \\
\hline
\end{tabular}

Pembagian data latih dan uji berdasarkan data pada Tabel 1. Proses Pelatihan dan pengujian dilakukan menggunakan LVQ dengan beberapa skenario yaitu ukuran citra, jumlah iterasi, dan laju pembelajaran. Ukuran citra yang digunakan adalah 100x100 pixel pixel, 300×300 pixel, 600x600 pixel, dan 1000x1000 pixel. Jumlah iterasi yang digunakan adalah 1000 epoch. Nilai laju pembelajaran $(\alpha)$ yang digunakan adalah 0,$01 ; 0,1 ; 0,3 ; 0,5$; dan 0,7 . Hasil pengujian dijadikan dalam bentuk matriks (Confussion Matrix) lalu dihitung akurasinya. Hasil pengujian model berdasarkan skenario ukuran citra, dan nilai laju pembelajaran dapat dilihat pada Gambar 8.

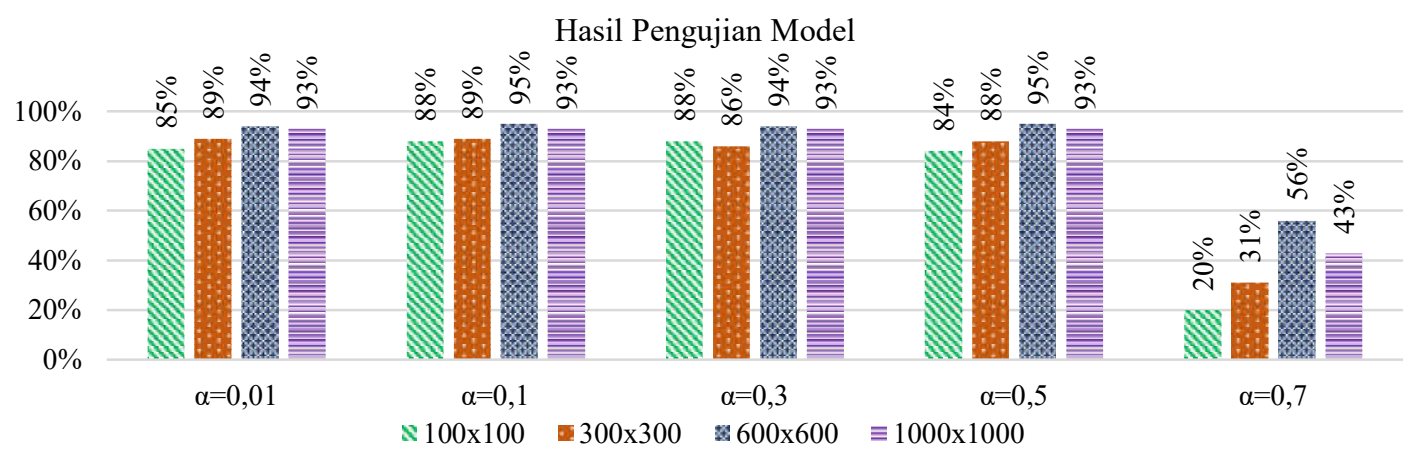

Gambar 8. Hasil pengujian model (100 citra gabungan dari empat sisi buah tomat) 
Berdasarkan hasil pengujian model seperti pada Gambar 8, rata-rata akurasi tertinggi dominan pada ukuran citra 600x600 pixel. Akurasi tertinggi mencapai $95 \%$ citra berukuran $600 \times 600$ pixel dengan nilai laju pembelajaran 0,1 dan 0,5.

Berdasarkan bobot hasil pengujian model menggunakan 100 citra hasil penggabungan, maka dilakukan pengujian pada 400 citra asli. Salah satu skenario hasil pengujian dengan model bobot yang dihasilkan dari pelatihan menggunakan 1000 epoch dan nilai laju pembelajaran 0,01 pada ukuran citra 100x100 pixel dapat dilihat pada Confussion Matrix Tabel 2

Tabel 2. Confussion matrix pengujian menggunakan 400 citra (citra setiap sisi buah tomat) dengan $\alpha=0,01$ pada ukuran citra $100 \times 100$ pixel

\begin{tabular}{|c|c|c|c|c|c|c|}
\hline & \multicolumn{5}{|c|}{ Kelas Prediksi } \\
\hline & & 1 & 2 & 3 & 4 & 5 \\
\hline \multirow{5}{*}{ 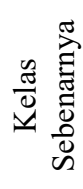 } & 1 & 71 & 2 & 7 & 0 & 0 \\
\hline & 2 & 9 & 41 & 26 & 1 & 3 \\
\hline & 3 & 8 & 11 & 52 & 8 & 1 \\
\hline & 4 & 0 & 0 & 6 & 68 & 6 \\
\hline & 5 & 0 & 0 & 4 & 2 & 74 \\
\hline
\end{tabular}

Berdasarkan matriks pengujian pada Tabel 2, maka akurasi pengujian menggunakan 400 citra dengan nilai laju pembelajaran 0,01 pada ukuran citra 100x100 pixel adalah sebagai berikut.

Akurasi $=\frac{71+41+52+68+74}{400} \times 100 \%=76,5 \%$

Grafik hasil pengujian secara keseluruhan dapat dilihat pada Gambar 9. Berdasarkan grafik pengujian pada Gambar 9, terlihat nilai laju pembelajaran memiliki pengaruh tetapi tidak terlalu signifikan, kecuali pada nilai laju pembelajaran 0,7 dan ukuran citra 100x100 pixel terjadi penurunan akurasi mencapai $20 \%$. Berdasarkan pengujian yang telah dilakukan, kesalahan klasifikasi dominan pada kelas Turning dan Pink seperti yang terlihat pada Tabel 2.

Hasil Pengujian Model Menggunakan Citra Setiap Sisi Buah Tomat

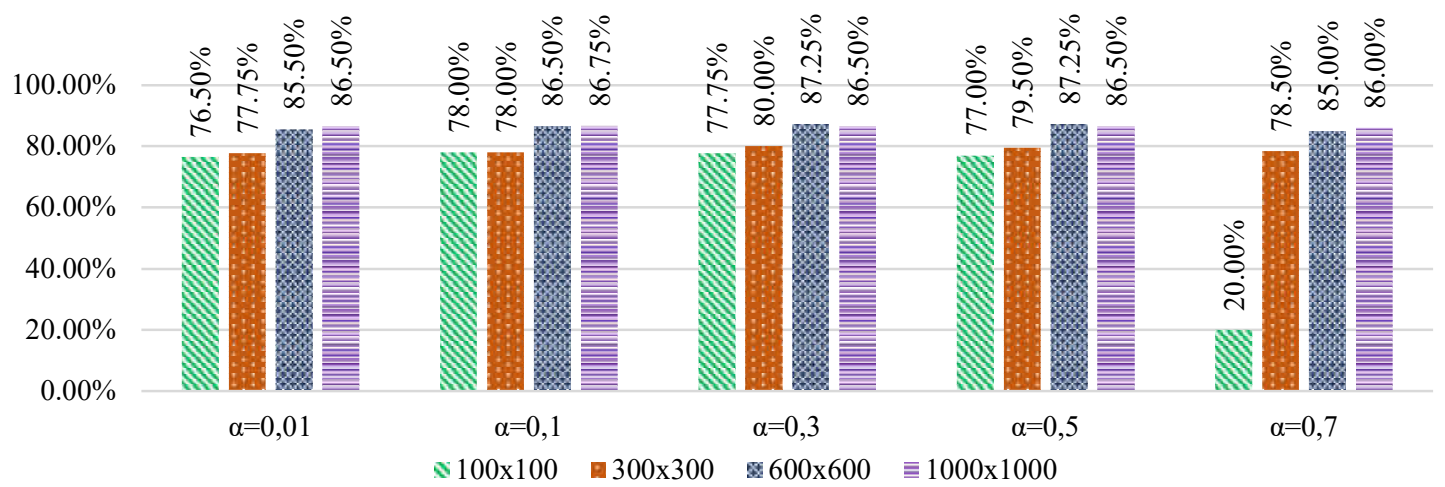

Gambar 9. Hasil pengujian menggunakan 400 citra asli (citra setiap sisi buah tomat)

\section{KESIMPULAN DAN SARAN}

Berdasarkan hasil Analisa dan pembahasan yang telah dilakukan, dapat disimpulkan ukuran citra, dan nilai laju pembelajaran dapat mempengaruhi hasil akurasi penentuan tingkat kematangan buah tomat. Akurasi tertinggi mencapai $87,25 \%$ dari 400 citra uji pada skenario nilai laju pembelajaran 0,3 dengan ukuran citra $600 \times 600$ pixel, dan skenario laju pembelajaran 0,5 dan $600 \times 600$ pixel. Nilai laju pembelajaran yang digunakan sebaiknya lebih kecil atau sama dengan 0,5 .

Pada proses pengambilan citra disarankan meminimalkan pantulan cahaya ketika mengambil gambar menggunakan foto, karena ada beberapa citra buah tomat memiliki pantulan cahaya dengan intensitas yang berbeda-beda, kemungkinan masalah tersebut yang menyebabkan kesalahan hasil klasifikasi pada beberapa pengujian.

\section{UCAPAN TERIMA KASIH}

Terima kasih kepada Lembaga Penelitian dan Pengabdian kepada Masyarakat (LPPM) UIN Sultan Syarif Kasim Riau yang telah memberikan dukungan baik moril maupun materil pada penelitian ini dan semua pihak yang terlibat sehingga penelitian ini dapat diselesaikan. 


\section{REFERENSI}

[1] A. Marliah, M. Hayati dan I. Muliansyah, "Pemanfaatan Pupuk Organik Cair Terhadap Pertumbuhan dan Hasil Beberapa Varietas Tomat (Lycopersicum esculentum L)," Jurnal Agrista, vol. 16, no. 3, pp. 122-128, 2012.

[2] S. Y. Riska dan P. Subekti, "Klasifikasi Level Kematangan Buah Tomat Berdasarkan Fitur Warna Menggunakan Multi-SVM," Jurnal Ilmiah Informatika, vol. 1, no. 1, pp. 39-24, 2016.

[3] USDA, "United States Standards for Grades of Fresh Tomatoes," United States Development of Agriculture, Washington, D.C, 1991.

[4] M. A. Anggriawan, M. Ichwan dan D. B. Utami, "Pengenalan Tingkat Kematangan Tomat Berdasarkan Citra Warna Pada Studi Kasus Pembangunan Sistem Pemilihan Otomatis," Jurnal Teknik Informatika dan Sistem Informasi (JuTISI), vol. 3, no. 3, pp. 550-564, 2017.

[5] G. Ramadhan, E. C. Djamal dan T. Darmanto, "Klasifikasi Identitas Wajah Untuk Otorisasi Menggunakan Deteksi Tepi dan LVQ," dalam Seminar Nasional Aplikasi Teknologi Informasi (SNATi), Yogyakarta, 2016.

[6] R. Abdillah, S. Sanjaya dan I. Afrianty, "The Effect of Class Imbalance Against LVQ Classification," dalam International Conference on Electrical Engineering and Informatics (ICon EEI) 2nd, Batam, Indonesia, 2018.

[7] A. S. Romadhon dan V. T. Widyaningrum, "Klasifikasi Mutu Jeruk Nipis Dengan Metode Learning Vector Quantization (LVQ)," Jurnal Ilmiah Rekayasa, vol. 8, no. 2, pp. 121-128, 2015.

[8] F. Astutik, "Sistem Pengenalan Kualitas Ikan Gurame dengan Wavelet, PCA, Histogram HSV dan KNN," LONTAR KOMPUTER, vol. 4, no. 3, pp. 336-346, 2013.

[9] Meiriyama, "Klasifikasi Citra Buah berbasis fitur warna HSV dengan klasifikator SVM," Jurnal Komputer Terapan, vol. 4, no. 1, pp. 50-61, 2018.

[10] N. Wijaya dan A. Ridwan, "Klasifikasi Jenis Buah Apel Dengan Metode K-Nearest Neighbors Dengan Ekstraksi Fitur HSV dan
LBP," Jurnal Sisfokom, vol. 8, no. 1, pp. 7478, 2019.

[11] S. Sanjaya, M. L. Pura, S. K. Gusti, F. Yanto dan F. Syafria, "K-Nearest Neighbor for Classification of Tomato Maturity Level Based on Hue, Saturation, and Value Colors," IJAIDM, vol. 2, no. 1, pp. 101-106, 2019.

[12] A. R. Smith, "Color gamut transform pairs," ACM Siggraph Computer Graphics, vol. 12, no. 3, pp. 12-19, 1978.

[13] S. Ozdemir, Principles of Data Science, Birmingham: Packt Publishing Ltd, 2016.

[14] T. Kohonen, "The self-organizing map," Proceedings of the IEEE, vol. 78, no. 9, pp. 1464-1480, 1990.

[15] L. Fausett, Fundamental of Neural Network: Architectures, Algorithms, and Application, New Jersey: Prentice Hall Inc, 1994.

[16] F. Gorunescu, Data Mining: Concepts, Models and Techniques, Springer, 2011. 